\title{
Introducing leprosy post-exposure prophylaxis into the health systems of India, Nepal and Indonesia: a case study
}

\author{
A. Tiwari ${ }^{1 *}$ (D) L. Mieras ${ }^{2}$, K. Dhakal ${ }^{3}$, M. Arif ${ }^{4}$, S. Dandel ${ }^{5}$, J. H. Richardus', LPEP Study Group
}

\begin{abstract}
Background: Leprosy has a wide range of clinical and socio-economic consequences. India, Indonesia and Nepal contribute significantly to the global leprosy burden. After integration, the health systems are pivotal in leprosy service delivery. The Leprosy Post Exposure Prophylaxis (LPEP) program is ongoing to investigate the feasibility of providing single dose rifampicin (SDR) as post-exposure prophylaxis (PEP) to the contacts of leprosy cases in various health systems. We aim to compare national leprosy control programs, and adapted LPEP strategies in India, Nepal and Indonesia. The purpose is to establish a baseline of the health system's situation and document the subsequent adjustment of LPEP, which will provide the context for interpreting the LPEP results in future.
\end{abstract}

Methods: The study followed the multiple-case study design with single units of analysis. The data collection methods were direct observation, in-depth interviews and desk review. The study was divided into two phases, i.e. review of national leprosy programs and description of the LPEP program. The comparative analysis was performed using the WHO health system frameworks (2007).

Results: In all countries leprosy services including contact tracing is integrated into the health systems. The LPEP program is fully integrated into the established national leprosy programs, with SDR and increased documentation, which need major additions to standard procedures. PEP administration was widely perceived as well manageable, but the additional LPEP data collection was reported to increase workload in the first year.

Conclusions: The findings of our study led to the recommendation that field-based leprosy research programs should keep health systems in focus. The national leprosy programs are diverse in terms of organizational hierarchy, human resource quantity and capacity. We conclude that PEP can be integrated into different health systems without major structural and personal changes, but provisions are necessary for the additional monitoring requirements.

Keywords: Leprosy, Health systems, Chemoprophylaxis, National Leprosy Control Programs

\section{Background}

Leprosy is an infectious disease, predominantly affecting peripheral nerves and the skin. It leads to a wide range of clinical symptoms, eventually resulting in disfigurement and disability if left untreated [1]. Additionally, the disease has severe socioeconomic consequences such as stigma and poverty, which may impact the patients and their families lifelong $[2,3]$. The WHO calls to globally interrupt leprosy transmission and reduce grade- 2

\footnotetext{
* Correspondence: a.tiwari@erasmusmc.nl

${ }^{1}$ Department of Public Health, Erasmus MC, University Medical Center Rotterdam, Office Na 2219, Wytemaweg 80, 3015 CN Rotterdam, The Netherlands

Full list of author information is available at the end of the article
}

disabilities in newly detected cases to below 1 per million population by 2020 [4]. However, current progress indicates that these targets are difficult to achieve $[5,6]$. In the year 2014, a total of 213,899 new cases were detected with a rate of 3.78 cases per 100,000 population. Southeast Asia accounted for $72 \%$ of the global new case load. India was the largest contributor (58.8\%), followed by Brazil (14.5\%) and Indonesia (8\%). Nepal identified 3046 new cases in 2014, which is around $2 \%$ of the total Southeast Asia burden [5]. Hence, India, Indonesia and Nepal are important contributors to the global burden of leprosy despite established and relatively well-resourced control programs, and 
elimination of leprosy (zero incidence) needs alternative control strategies.

After integration, the general health systems are pivotal for leprosy service delivery. A health system is defined as "the combination of resources, organization, financing and management that culminate in the delivery of health services to the population" [7]. Early case detection and subsequent treatment with multi-drug therapy (MDT) are the key strategies to reduce the disease burden $[8,9]$. Health systems however, do not appear to be efficient in detecting cases early, as the grade 2 disability rate remained stable (between 0.23 to 0.25 per 100,000 population) over the last 10 years [5]. Furthermore, the stagnation in the new case detection rate (NCDR) and relatively high child case rates in many countries indicate that transmission of Mycobacterium leprae, the causative agent of leprosy, is ongoing and that current methods, including MDT, are insufficient to break transmission [10, 11]. The transmission of the $M$. leprae bacteria is complex poorly understood $[12,13]$. Also, it has been argued that leprosy programs are not implemented properly $[6,14]$, and needs to be improved $[15,16]$.

There is sufficient evidence that chemoprophylaxis with Single Dose Rifampicin (SDR) is efficacious in reducing the risk of developing leprosy among contacts of leprosy patients $[17,18]$. It has thus been recommended to assess the effectiveness of SDR in different field settings [19]. Therefore, the Leprosy Post-Exposure Prophylaxis (LPEP) program was initiated by different stakeholders in close collaboration with the ministries of health of eight countries - India, Nepal, Indonesia, Myanmar, Sri Lanka, Tanzania, Brazil and Cambodia. LPEP activities started in 2014 for a duration of three years. The objective of LPEP is to assess the impact on the new case detection rate, measured through strengthened surveillance and reporting systems and its feasibility in diverse routine programme settings. The program has three prime components: Contact tracing; screening; and SDR administration. It is designed to complement and be integrated into the national leprosy control programs, rather than operating vertically. Moreover, it aims to contribute to the strengthening of the general health care systems by providing support in human resources, training and program monitoring.

The primary objective of this work is to compare national leprosy control programs and adapted LPEP strategies in India, Nepal and Indonesia. The secondary objective is to summarize the lessons learned during the first year of implementation.

\section{Methods}

\section{LPEP program sites}

In India, the program is operating in the union territory (UT) of Dadra and Nagar Haveli (DNH), situated in the west of India between the state of Gujarat and Maharashtra. Nepal is implementing the program in the tarai (plains) districts of Jhapa, Morang and Parsa. All three districts share boundaries with India. In Indonesia LPEP is implemented in Sumenep district, which is a regency of East Java province, situated on the eastern end of Madura Island. All intervention areas are high leprosy endemic and have been selected based on the recommendations of the respective ministry of health (Table 1).

\section{Study design}

The study followed the multiple-case study design with single units of analysis [20]. The case study methodology was selected because it was suitable for the objective of the research, i.e. comparing LPEP (case) in the context of the national leprosy control programs. Furthermore, the selected methodology enables exploratory analysis by using data from multiple sources. The study aims to cover a broader range of complex field conditions that have a role in developing LPEP strategies in each country.

\section{Data collection}

We collected quantitative and qualitative data. The data collection methods were direct observations (facility and

Table 1 Demographic, geographical and epidemiological profile (2015-16) of the LPEP program sites

\begin{tabular}{|c|c|c|c|c|c|}
\hline \multirow{2}{*}{$\begin{array}{l}\text { Country (2015-16) } \\
\text { Sub-national area }\end{array}$} & \multirow{2}{*}{$\begin{array}{l}\text { India } \\
\text { Dadra \& Nagar Haveli, UT }\end{array}$} & \multicolumn{3}{|l|}{ Nepal } & \multirow{2}{*}{$\begin{array}{l}\text { Indonesia } \\
\text { Sumenep Distric }\end{array}$} \\
\hline & & Jhapa District & Morang District & Parsa District & \\
\hline Population & 427,462 & 887,023 & $1,044,071$ & 660,249 & $1,059,000$ \\
\hline Area $\left(\mathrm{km}^{2}\right)$ & 491 & 1606 & 1855 & 1353 & 1998 \\
\hline New cases detection rate (NCDR/100,000) & 99.4 & 20.97 & 19.3 & 16.56 & 43.3 \\
\hline Percent new cases of MB leprosy & 26.5 & 60.75 & 49.0 & 41.44 & 76.3 \\
\hline Percent new cases with DGll & 1.8 & 2.69 & 1 & NA & 5.5 \\
\hline \multicolumn{6}{|l|}{ Percent new cases: } \\
\hline - Females & 57.8 & 46.24 & 44 & 25.22 & 46.2 \\
\hline - Children & 23.2 & 3.76 & 8.9 & 5.40 & 6.5 \\
\hline
\end{tabular}

UT Union Territory, NA Information not available, NCDR New Case Detection Rate, MB Multi Bacillary, DGII Disability Grade II 
service delivery), interviews (open-ended and semistructured conversations) with the staff at various levels, and desk review. The type of information (online and printed) reviewed were peer reviewed publication, department reports, and other program documents such as guidelines, training manuals and annual report.

The study was divided into two phases (Table 2). In the first phase, we reviewed the national leprosy control programs in the three countries. The first set of data was collected through desk review, followed by a field visit in each country between April 2015 and January 2016. The desk review aimed to identify documents describing the standard operating procedures and policies of the national leprosy programs, whereas the objectives of the field visits were to interview staff and observe onsite activities. During field visits, we collected relevant documents that were not available online. The staff at the national, provincial and field level were interviewed to assess perceived reasons behind current epidemiological trends, and to describe their routine practices and associated challenges. An additional file shows this in more detail [see Additional file 1]. Furthermore, we verified the standard operating procedures and data trends published by the national programs during interviews. The first phase data were then used to assess and compare the different national programs and describe a baseline for LPEP.

In the second phase, we reviewed the LPEP activities at study site level, i.e. UT of Dadra and Nagar Haveli in India, Morang and Jhapa districts of Nepal, and Sumenep district of Indonesia. We visited each country twice between April and November 2015, after the inception of LPEP. The data collection methods were identical with the ones used in the first phase. Quantitative data were mainly related to the program coverage. The qualitative data were collected on the LPEP implementation practices. We focused on the difference between planned and actual implementation [21]. The health staff were interviewed to describe LPEP practices for various activities such as SDR distribution, contact tracing, screening, recording and reporting. The focus was on the coordination and integration of activities with the national leprosy programs. Finally, respondents were asked about the challenges faced during the pilot. A special focus was on the anticipated integration of PEP into the national programs.

\section{Data analyses}

The national leprosy control programs are part of the general health care system, and LPEP is integrated into it. Therefore, we adopted the WHO health system framework $[22,23]$ to outline the main components of the health system, as presented in Fig. 1.

These components were elaborated by the common emerging themes, identified from the primary and secondary data from the first phase and second phase.

We used the epidemiological (quantitative) data to assess the leprosy situation and the (qualitative) data on implementation to depict the program and LPEP project functioning respectively. The qualitative data on standard operating procedures and actual implementation were verified to minimize bias and assess similar patterns.

\section{Results}

\section{National Leprosy Control Programs}

The general health care system is based on a three-tier structure in all reviewed LPEP countries, i.e. national, provincial and district level (Fig. 2).

The Indian leprosy program is called the National Leprosy Elimination Program (NLEP), whereas the Nepal

Table 2 Details of the data collection methods, data type and sources

\begin{tabular}{|c|c|c|}
\hline Data Collection Method & Type of data and sources & Nature \\
\hline \multicolumn{3}{|c|}{ Phase I: National Leprosy Programs } \\
\hline Desk review & $\begin{array}{l}\text { Secondary data from scientific papers, } \\
\text { archival records and document on } \\
\text { national leprosy control programs }\end{array}$ & $\begin{array}{l}\text { Quantitative data on the epidemiology } \\
\text { and performance of the programs. } \\
\text { Qualitative data on the SOP and policies }\end{array}$ \\
\hline Direct observation & Primary data & $\begin{array}{l}\text { Qualitative observations of the activities such } \\
\text { as contact tracing, treatment rehabilitation, etc. }\end{array}$ \\
\hline Interviews & Primary data & $\begin{array}{l}\text { Qualitative data on explanations of epidemiological } \\
\text { trends, routine functioning, challenges and solutions }\end{array}$ \\
\hline \multicolumn{3}{|l|}{ Phase II: LPEP Program } \\
\hline Desk review & $\begin{array}{l}\text { Secondary data on LPEP service } \\
\text { delivery from MIS }\end{array}$ & Quantitative data on the coverage of services \\
\hline Direct observation & Primary data & $\begin{array}{l}\text { Qualitative observations of the LPEP activities } \\
\text { such as screening, SDR distribution and recording } \\
\text { \& reporting }\end{array}$ \\
\hline Interviews & Primary data & $\begin{array}{l}\text { Qualitative data on LPEP routine functioning, } \\
\text { challenges and solutions }\end{array}$ \\
\hline
\end{tabular}




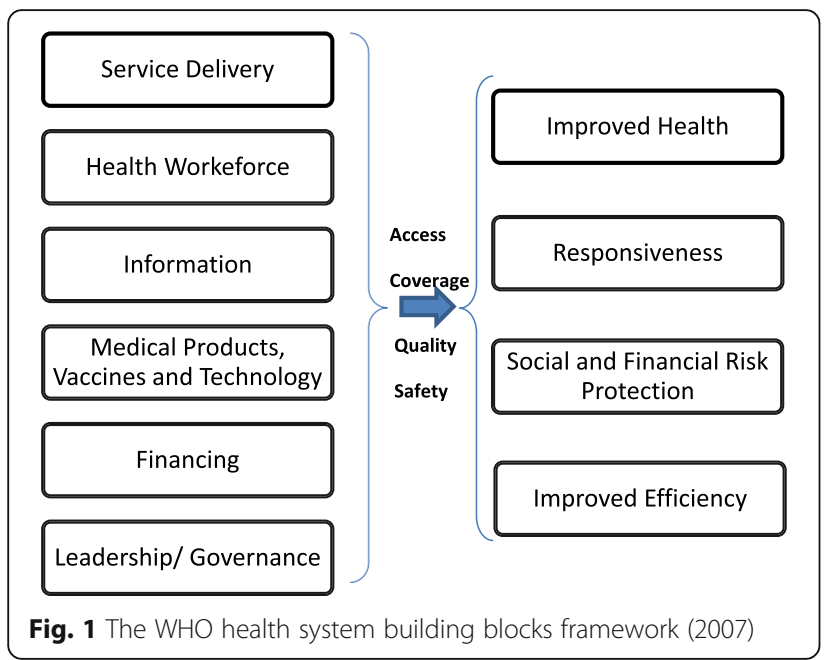

and Indonesian programs are indicated as National Leprosy Control Program (NLCP). An additional file lists the official leprosy control/elimination strategies [see Additional file 2]. The leprosy control programs are operational throughout the countries, however, special attention is given to the high endemic areas. Case detection is mainly passive, although India and Indonesia reported instances of outreach leprosy activities, integrated or non-integrated with other diseases. The periodicity and focus of such activities (only in high endemic areas) is not fixed, and varies depending on the local situation and available means. Contact tracing was already a part of all reviewed leprosy programs before LPEP, but in practice only household contacts were covered in all three countries. The programs in Nepal and Indonesia depend largely on the paramedical staff located on the peripheries. The role of doctors is limited to the confirmation of unclear cases and management of complicated cases at higher levels. The presence and support of volunteers is strongest in India as compared to the other countries. Volunteers are actively engaged in information dissemination, suspect identification, and monitoring treatment adherence. The comparative details of national programs are listed in Table 3.

The overall implementation process and the coordination between different staff levels is comparable in the three countries (Fig. 3).

Service delivery is integrated into the general health care system in all three countries. However, central leprosy divisions have an extensive role in planning, funding and monitoring. The Indonesian health system is the most decentralized in terms of higher autonomy of districts in planning and allocating funds between diseases or activities. Next, MDT supply is based on the demand, i.e. case load of health facilities. Mostly the supply chain is smooth, but short periods of out-of-stock instances were reported from peripheral centres in Nepal. The general health care staff are involved in the implementation of the leprosy
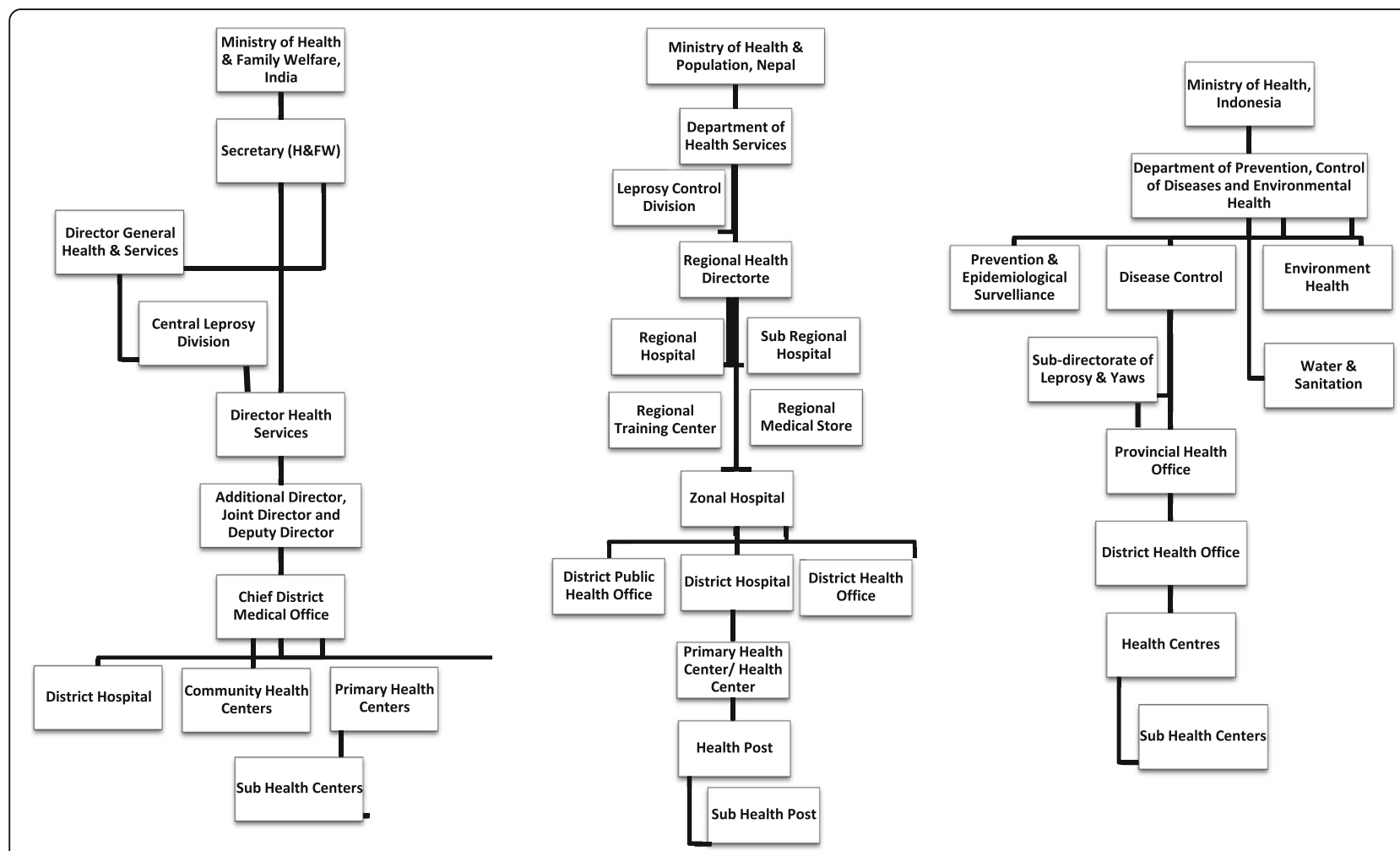

Fig. 2 Organogram of the Health Services in India, Nepal and Indonesia 
Table 3 Description of National Leprosy Control/Elimination Programs in India, Nepal and Indonesia based on WHO framework

\begin{tabular}{|c|c|c|c|c|}
\hline $\begin{array}{l}\mathrm{WHO} \\
\text { Framework }\end{array}$ & Themes & NLEP India & NLCP Nepal & NLCP Indonesia \\
\hline \multirow[t]{9}{*}{$\begin{array}{l}\text { Service } \\
\text { Delivery }\end{array}$} & $\begin{array}{l}\text { Coverage } \\
\text { (Prevalence) } 2014\end{array}$ & $\begin{array}{l}88,833 \text { cases registered } \\
\text { and treated (Source: Global } \\
\text { leprosy update 2014) }\end{array}$ & $\begin{array}{l}2382 \text { cases registered and } \\
\text { treated (Source: Global leprosy } \\
\text { update 2014) }\end{array}$ & $\begin{array}{l}19,949 \text { cases registered } \\
\text { and treated (Source: Global } \\
\text { leprosy update 2014) }\end{array}$ \\
\hline & Infrastructure & $\begin{array}{l}\text { 153,655 Sub Center; } 25,308 \\
\text { PHCs; } 5396 \text { CHCs (Source: Rural } \\
\text { Health Statistics 2015, India) }\end{array}$ & $\begin{array}{l}208 \text { PHCs; } 1559 \text { HPs; } 2643 \text { SHP } \\
\text { (Source: Annual Report 2013-14, } \\
\text { Dept. of Health, Nepal) }\end{array}$ & $\begin{array}{l}3395 \text { HCs with IPD and } \\
6345 \text { HCs with only OPD } \\
\text { (Source: Jumlah Puskesmas } \\
\text { 2015, Indonesia) }\end{array}$ \\
\hline & \multirow[t]{5}{*}{ Activities } & $\begin{array}{l}\text { Case detection is mainly } \\
\text { passive with few periodic } \\
\text { active outreach }\end{array}$ & $\begin{array}{l}\text { Case detection is } \\
\text { mainly passive }\end{array}$ & $\begin{array}{l}\text { Case detection is mainly } \\
\text { passive with few periodic } \\
\text { active outreach }\end{array}$ \\
\hline & & $\begin{array}{l}\text { Routine household } \\
\text { contact tracing }\end{array}$ & $\begin{array}{l}\text { Routine household } \\
\text { contact tracing }\end{array}$ & $\begin{array}{l}\text { Routine household contact } \\
\text { tracing; integrated SDR since } \\
2012 \text { in two districts }\end{array}$ \\
\hline & & $\begin{array}{l}\text { Suspect identification \& their } \\
\text { adherence is checked by } \\
\text { volunteers (ASHA) at field level }\end{array}$ & $\begin{array}{l}\text { Suspect identification \& their } \\
\text { adherence is checked by } \\
\text { volunteers (FCHV) at field level }\end{array}$ & $\begin{array}{l}\text { Suspect identification \& their } \\
\text { adherence is checked by } \\
\text { paramedical staff (village midwife) }\end{array}$ \\
\hline & & $\begin{array}{l}\text { Contact screening by } \\
\text { paramedical staff (PMW/ANM) } \\
\text { at sub-center }\end{array}$ & $\begin{array}{l}\text { Contact screening by } \\
\text { paramedical staff (Leprosy } \\
\text { Focal Person) at Health Post }\end{array}$ & $\begin{array}{l}\text { Contact screening by paramedics } \\
\text { staff (Leprosy officer) at HC }\end{array}$ \\
\hline & & $\begin{array}{l}\text { Confirmation diagnosis by } \\
\text { doctor at PHC and higher }\end{array}$ & $\begin{array}{l}\text { Confirmation diagnosis by } \\
\text { Leprosy focal person / doctor } \\
\text { at Health Post and higher }\end{array}$ & $\begin{array}{l}\text { Confirmation diagnosis by } \\
\text { Leprosy officer at } \mathrm{HC} \text { and } \\
\text { doctor at higher level }\end{array}$ \\
\hline & Process & & Refer Fig. 3 & \\
\hline & $\begin{array}{l}\text { MDT supply } \\
\text { (Source: Interviews) }\end{array}$ & $\begin{array}{l}\text { No stock out situation } \\
\text { reported at peripheral level }\end{array}$ & $\begin{array}{l}\text { Seldom stock out situation } \\
\text { reported for a very short } \\
\text { period at peripheral level }\end{array}$ & $\begin{array}{l}\text { A major stock out situation } \\
\text { reported in } 2016 \text { at peripheral level }\end{array}$ \\
\hline \multirow[t]{2}{*}{$\begin{array}{l}\text { Health } \\
\text { Workforce }\end{array}$} & Staff & $\begin{array}{l}\text { General health care staff. } \\
\text { High epidemic PHCs have } \\
\text { additional staff }\end{array}$ & General health care staff & General health care staff \\
\hline & Leprosy Training & $\begin{array}{l}10,624 \text { Doctors, } 24,255 \\
\text { Paramedics and 104,011 } \\
\text { volunteers trained on } \\
\text { leprosy (Source: NLEP } \\
\text { Progress Report 2014-15) }\end{array}$ & $\begin{array}{l}150 \text { health worker trained } \\
\text { on leprosy. (Source: Annual } \\
\text { Report 2013-14, Dept. of } \\
\text { Health, Nepal) }\end{array}$ & $\begin{array}{l}120 \text { Doctors, } 516 \text { leprosy staff } \\
\text { trained on leprosy in } 2014 \\
\text { (Source: Subdit Kusta 2014, Indonesia) }\end{array}$ \\
\hline \multirow[t]{4}{*}{ Information } & Indicators & $\begin{array}{l}\text { Standard set of indicators } \\
\text { as per WHO }\end{array}$ & $\begin{array}{l}\text { Standard set of indicators } \\
\text { as per } \mathrm{WHO}\end{array}$ & $\begin{array}{l}\text { Standard set of indicators as } \\
\text { per WHO }\end{array}$ \\
\hline & Data Management & $\begin{array}{l}\text { Individual at sub-center } \\
\text { level, then aggregated. }\end{array}$ & $\begin{array}{l}\text { Individual at health-post level, } \\
\text { then aggregated. General MIS } \\
\text { electronic entry at district level } \\
\text { but limited leprosy indicators. }\end{array}$ & $\begin{array}{l}\text { Individual at sub-center level, } \\
\text { then aggregated }\end{array}$ \\
\hline & $\begin{array}{l}\text { Supervision \& } \\
\text { Monitoring }\end{array}$ & $\begin{array}{l}\text { CLD State Leprosy Office } \\
\& \text { District Leprosy Officer }\end{array}$ & $\begin{array}{l}\text { CLD, Regional Health Directorate } \\
\text { and District Health / Public } \\
\text { Health officer }\end{array}$ & $\begin{array}{l}\text { Department of Leprosy \& Yaws } \\
\text { (central), Provincial Leprosy Office } \\
\text { and District Health Office }\end{array}$ \\
\hline & Reporting & $\begin{array}{l}\text { Monthly, quarterly and Annually. } \\
\text { Bottom-up at all levels }\end{array}$ & $\begin{array}{l}\text { Monthly, quarterly and Annually. } \\
\text { Bottom-up at all levels }\end{array}$ & $\begin{array}{l}\text { Monthly, quarterly and Annually. } \\
\text { Bottom-up at all levels }\end{array}$ \\
\hline Innovation & New initiatives & Developed M.W vaccine & NA & NA \\
\hline \multirow[t]{2}{*}{ Financing } & Budget & $\begin{array}{l}\text { NLEP total budget decreased by } \\
9.8 \% \text { from } 2014 \text { to } 15 \text { to } 2015-16 \\
\text { (Source: MoHFW, Outcome } \\
\text { Budget } 2014-15 \text { \& 2015-16) }\end{array}$ & $\begin{array}{l}\text { NLCP recurrent budget (released) } \\
\text { was increased by } 58 \% \text { from } 2012 \\
\text { to } 13 \text { to } 2013-14 \text { (Source: Annual } \\
\text { Report Dept. of Health, 2012-13 } \\
\& \text { 2013-14) }\end{array}$ & NA \\
\hline & Funding & CLD and State Leprosy Office & Ministry of Health and Population & $\begin{array}{l}\text { Sub-directorate Leprosy \& } \\
\text { Yaws and District Health Office }\end{array}$ \\
\hline
\end{tabular}


Table 3 Description of National Leprosy Control/Elimination Programs in India, Nepal and Indonesia based on WHO framework (Continued)

\begin{tabular}{|c|c|c|c|c|}
\hline WHO & Themes & NLEP India & NLCP Nepal & NLCP Indonesia \\
\hline & OOPs in leprosy & & No evidence & \\
\hline & $\begin{array}{l}\text { Periodicity of funds } \\
\text { (Source: Interviews) }\end{array}$ & $\begin{array}{l}\text { Sometimes delay in salary } \\
\text { disbursement at peripheral } \\
\text { level or case reimbursements } \\
\text { to ASHA }\end{array}$ & $\begin{array}{l}\text { Sometimes delay in salary } \\
\text { disbursement at peripheral } \\
\text { level or case reimbursements } \\
\text { to FCHV }\end{array}$ & Mostly on time \\
\hline \multirow[t]{3}{*}{ Governance } & National Strategy & $\begin{array}{l}\text { Strategy focus on decentralization } \\
\text { of leprosy services. For more } \\
\text { information, refer Additional file } 1\end{array}$ & $\begin{array}{l}\text { Strategy focus on disability } \\
\text { and rehabilitation. For more } \\
\text { information, refer Additional file } 1\end{array}$ & $\begin{array}{l}\text { Strategy focus on } \\
\text { early detection. } \\
\text { For more information, } \\
\text { refer Additional file } 1\end{array}$ \\
\hline & $\begin{array}{l}\text { Organization } \\
\text { structure }\end{array}$ & & Fig. 2 & \\
\hline & Integration & $\begin{array}{l}\text { Integrated into general health } \\
\text { system }\end{array}$ & $\begin{array}{l}\text { Integrated into general health } \\
\text { system }\end{array}$ & $\begin{array}{l}\text { Integrated into general health } \\
\text { system }\end{array}$ \\
\hline
\end{tabular}

ANM Auxiliary Nurse Midwife, ASHA Accredited Social Health Activist, CHC Community Health Center, CLD Central Leprosy Division, FCHV Female Community Health Volunteer, HC Health Center, HP Health Post, LFP Leprosy Focal Person, MPW Multipurpose Worker, NA Not Available, PHC Primary Health Center, PMW Para Medical Worker, SHP Sub-Health Post

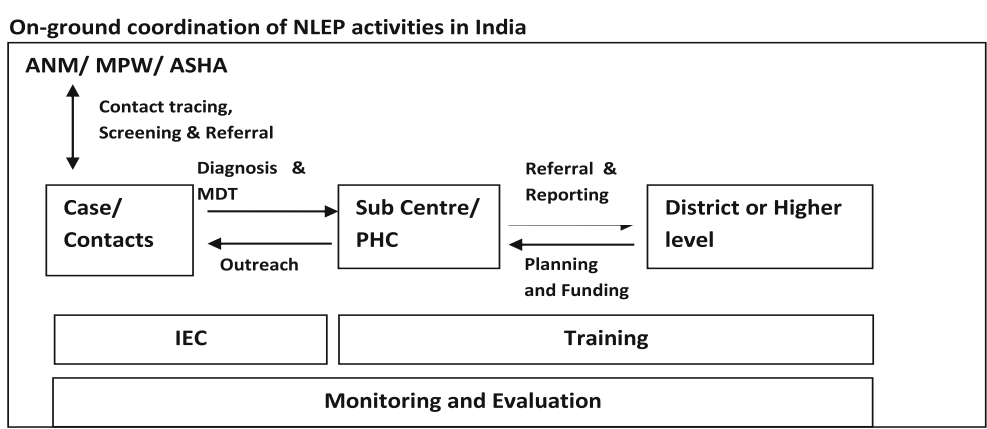

ANM: Auxiliary Nurse Midwife, MPW: Multipurpose Worker, ASHA: Accredited Social Health Activist On-ground coordination of NLCP activities in Nepal

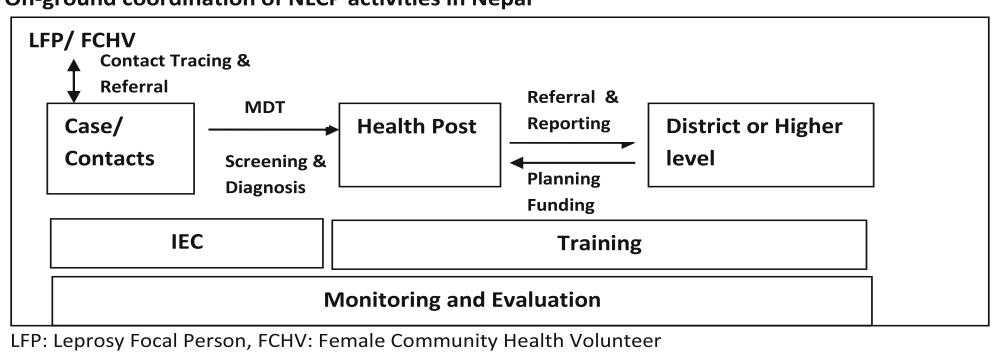

LFP: Leprosy Focal Person, FCHV: Female Community Health Volunteer

On-ground coordination of NLCP activities in Indonesia

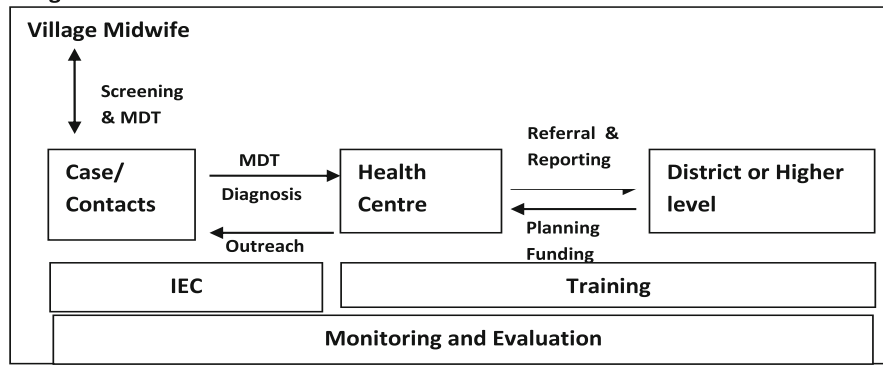

Fig. 3 Diagram illustrating the implementation process under the National Leprosy Control / Elimination Programs in India, Nepal and Indonesia 
program, but in India high endemic districts occasionally receive top-up human resource budgets under the NLEP. In all countries training is the shared responsibility of provincial and district health departments. The recording and reporting includes all the indicators prescribed by WHO to estimate the burden $[5,8,9]$. Other reported indicators are on coverage of services, which varies between countries due to difference in activities. Nepal has developed an electronic database portal named WeBLeRS, capable of individual level data entry. Unfortunately, WeBLeRS is only used in a limited number of high endemic districts. Remaining countries are recording individual data on paper which remains at the field level. Subsequently, the aggregated data is reported to higher levels. Supervision and reporting follow the same structure and periodicity in all the three countries (Figs. 3 and 4).

\section{LPEP inception and target population}

The LPEP field activities started in March 2015 in India, covering retrospective cases and contacts of the last two years. In Nepal, LPEP was slightly delayed due to the earthquake on 25 April 2015, therefore field implementation started in May 2015, covering retrospective cases and contact of the last one year. In Indonesia LPEP field implementation started in January 2015, with no target to cover retrospective cases. Instead, all leprosy cases diagnosed since January 1st 2015 are aimed to be covered, excluding the cases of 8 health centres, located on the remote islands of that regency in Indonesia. These islands are hard to reach and accessibility is limited.

\section{LPEP implementation comparison}

The LPEP service delivery in all three countries is fully integrated into the general health care systems. Indonesia is practicing extended contact tracing using self-screening, whereas in India and Nepal the contacts are screened by paramedical staff. In the case of selfscreening, the first field visit is dedicated to Information Education and Communication (IEC) on self-screening, followed by a second field visit (after 2-3 days) for investigation of self-reported suspects and SDR administration (Fig. 4).

In India, contacts are defined as Household, Neighbours and Social contacts (only school class fellows), whereas in Nepal and Indonesia only Household and Neighbours contacts are included. The minimum age to provide SDR is 2 years in all the three countries. Common activities include line listing, contact tracing, screening, SDR administration, recording, reporting and monitoring (Fig. 4). Rifampicin is procured by the local Department of Health in all the three countries. LPEP appointed staff in India are LPEP supervisor $(n=1)$ and research assistants $(n=4)$. The Nepal program is supported by a LPEP manager $(\mathrm{n}=1)$ and district supervisors $(n=3)$, whereas

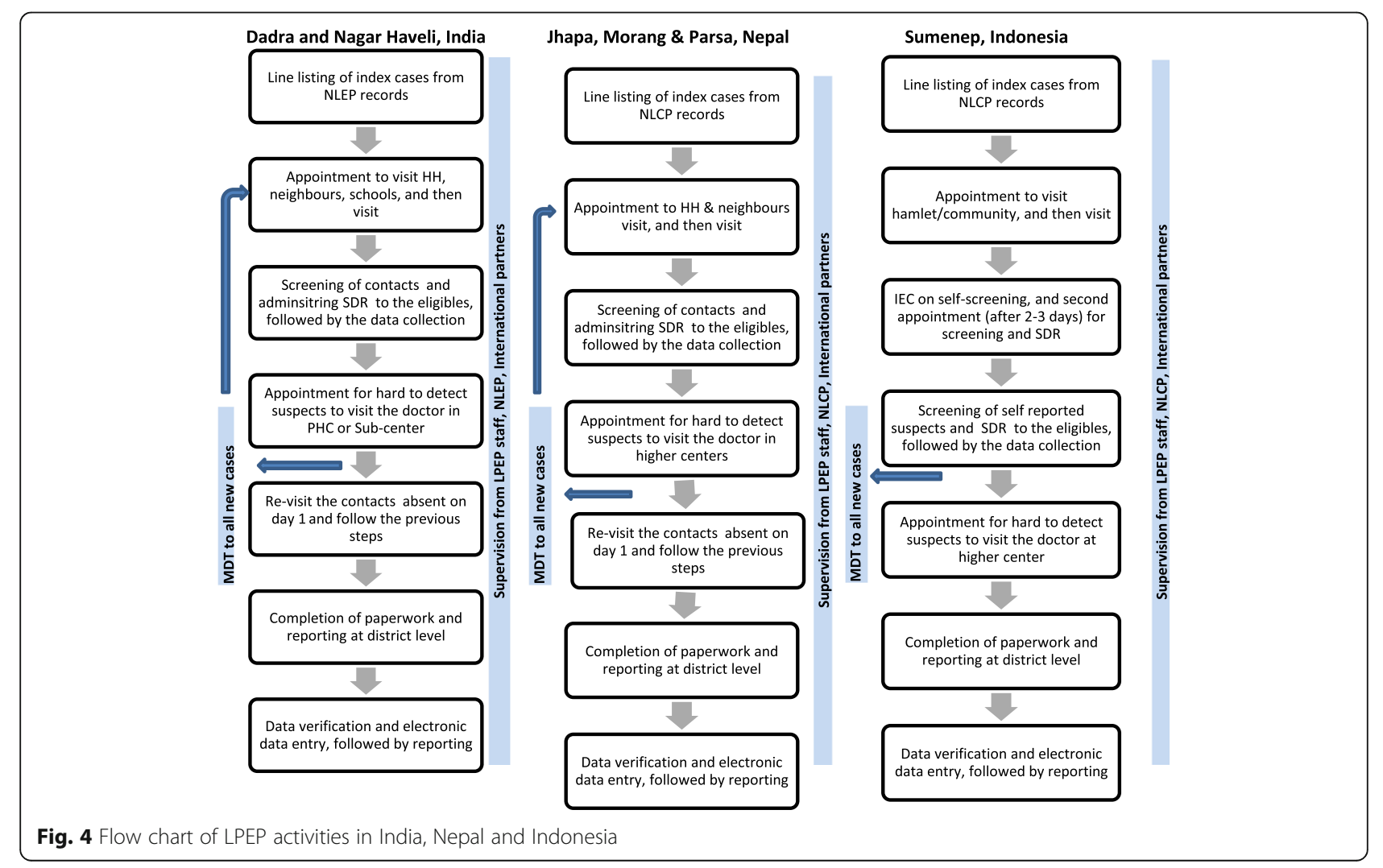


Indonesia appointed only a LPEP manager $(n=1)$. The staff dedicate their full time to conduct training, supervision, assistance and reporting. All LPEP staff were trained in Training of Trainers (ToT) just before the program field implementation. Two types of trainings were imparted in all three countries, i.e. operational training and data management training. The LPEP data is collected on paper forms in the field, and reported to district level where electronic data entry takes place. A similar Microsoft Access database is used in all three countries, which collects demographic, epidemiological, clinical and coverage indicators. The supervision and monitoring structure is similar in all countries. Furthermore, Indonesia distributes IEC hand fans and packed drinking water during leprosy activities. The NGO funds are reported to be disbursed on time, however the government disbursements are aligned with the national program's schedule. The comparative details of LPEP are listed in Table 4.

\section{Challenges in the first year of implementation}

The initial months of the program field work were characterized by intense activities, due to the recruitment of retrospective leprosy cases. The country programs have been implemented by the general health care staff, after striking a balance between LPEP and other disease programs. The most common problem reported by the staff was the additional data collection work load (especially, filling of consent forms of cases and contacts) due to the research nature of the program. Next, not all contacts are present on the screening day, therefore health staff need to visit 2-3 times to achieve optimal coverage. Participation of male contacts is lower compared to females because they are more often out of the home to work. According to the field staff, refusals are more common in urban areas than rural areas, probably due to stigma, therefore more efforts reported to be deployed in urban areas to explain the program and the significance of SDR. A particular challenge is that houses are often dark while good light is required for screening, but females cannot be screened in the open.

\section{Discussion}

The general health care system is the covering umbrella of leprosy services, thus we emphasize that all field-based leprosy research should be aligned with the local health system realities. The above statement is more relevant in a post global elimination scenario, when resources are reduced, but the pressure is high to deliver pragmatic results [24]. Correspondingly, feasibility also depends on the capacity of the health systems to accommodate new interventions. Systematic and sustained health system strengthening is important. Continuous and coordinated efforts are needed from various components (including disease specific programs) of a health system $[25,26]$. For example, the coordination between leprosy and TB departments is desired to collectively deal with the risk of rifampicin resistance and to ensure proper follow-up of suspected TB cases identified in the frame of leprosy screening [27, 28]. Furthermore, leprosy service delivery also experiences common limitations of a weak health system such as poor accessibility, availability, affordability and quality [29-31]. Despite that the cross cutting evidence on leprosy and health systems is limited. As an exception, integration of vertical leprosy programs into the general health care system is a well-documented topic [32]. Most of the experiences however, are in the form of commentaries on individual cases. We recommend to synthesize the available literature on integration in a systemic way to highlight the differences and derive a framework, which can be further developed into a standardize tool to measure the level of integration. This is relevant because leprosy programs are partially integrated in many countries and such a tool can help in measuring performance over time. Further, the framework can be applied to other vertical programs.

The London Declaration recommends to increase funding for leprosy and other Neglected Tropical Diseases (NTDs) [4]. However, funding continues to decline, e.g. the total budget of NLEP India was decreased by $9.8 \%$ from 2014 to 2016 [33, 34]. Besides public funding, national leprosy programs should also promote inclusion of their services into other financial risk protection schemes [35]. In many high epidemic countries, state run insurance schemes are operational [36]. The leprosy programs should strive for a high coverage of their target population under such schemes, as leprosy poses a high financial risk [37].

Our study showed that the national leprosy programs as part of the health systems are diversified in the three countries, based on organizational hierarchy, human resource quantity and capacity. Further, the compatibility between LPEP and national programs is high, as the existing contact tracing system (including infrastructure and staff) is retained and strengthened. As a result, contact tracing is intensified, but needs to be maintained after LPEP program completion. The ownership of the program lies with the government, and their active involvement increases the chances of integration of SDR into national policies, if the results are promising. The LPEP program has introduced simple but important innovations such as digital information system.

As a limitation, this study summarised the national leprosy programs mainly based on the secondary data. The primary data was collected only at LPEP sites (high endemic), which are small geographical units in the countries. There is a possibility of variation in the activities or intensity of national leprosy programs in other parts of the countries, especially low or medium endemic area. 
Table 4 Description of LPEP country programs in India, Nepal and Indonesia based on WHO framework

\begin{tabular}{|c|c|c|c|c|}
\hline $\begin{array}{l}\text { WHO } \\
\text { Framework }\end{array}$ & Themes & LPEP Dadra and Nagar Haveli, India & LPEP Morang, Jhapa and Parsa, Nepal & LPEP Sumenep, Indonesia \\
\hline \multirow[t]{9}{*}{$\begin{array}{l}\text { Service } \\
\text { Delivery }\end{array}$} & $\begin{array}{l}\text { Average } \\
\text { coverage } \\
(2015-16)\end{array}$ & $\begin{array}{l}\text { SDR coverage is average } 22 \\
\text { contacts per index case }\end{array}$ & $\begin{array}{l}\text { SDR coverage is average } 23 \\
\text { contacts per index case }\end{array}$ & $\begin{array}{l}\text { SDR coverage is average } 33 \\
\text { contacts per index case }\end{array}$ \\
\hline & Infrastructure & General health care system & General health care system & General health care system \\
\hline & \multirow[t]{5}{*}{ Activities } & $\begin{array}{l}\text { Line listing of } \mathrm{HH} \text {, Neighbours } \\
\text { and social contacts }\end{array}$ & Contact tracing of $\mathrm{HH}$ and Neighbours & $\begin{array}{l}\text { Contact tracing of } \mathrm{HH} \\
\text { and Neighbours }\end{array}$ \\
\hline & & $\begin{array}{l}\mathrm{HH} \text {, neighbours and school } \\
\text { visits by volunteers (ASHA) } \\
\text { and paramedics (ANM/PMW) }\end{array}$ & $\begin{array}{l}\mathrm{HH} \text { and neighbours visits by volunteers } \\
(\mathrm{FCHV}) \text { and paramedics (LFP) }\end{array}$ & $\begin{array}{l}\text { Community gathering by village } \\
\text { midwife and paramedics (LO) }\end{array}$ \\
\hline & & $\begin{array}{l}\text { Individual screening of } \\
\text { contacts by paramedics }\end{array}$ & $\begin{array}{l}\text { Individual screening of } \\
\text { contacts by paramedics }\end{array}$ & $\begin{array}{l}\text { Self-screening and then re-screening } \\
\text { of the suspects by paramedics }\end{array}$ \\
\hline & & $\begin{array}{l}\text { SDR distribution immediately } \\
\text { after screening }\end{array}$ & $\begin{array}{l}\text { SDR distribution immediately } \\
\text { after screening }\end{array}$ & $\begin{array}{l}\text { SDR distribution after 2-3 days of } \\
\text { IEC on self-screening }\end{array}$ \\
\hline & & Onsite data collection (paper forms) & Onsite data collection (paper forms) & Onsite data collection (paper forms) \\
\hline & Process & Refer Fig. 4 & Refer Fig. 4 & Refer Fig. 4 \\
\hline & SDR supply & $\begin{array}{l}\text { Rifampicin is procured by } \\
\text { Dept. of Health in al dosages. } \\
\text { Syrups available }\end{array}$ & $\begin{array}{l}\text { Rifampicin is procured by Dept. } \\
\text { of Health in all dosage. Syrups } \\
\text { not available }\end{array}$ & $\begin{array}{l}\text { Rifampicin is procured by Dept. } \\
\text { of Health in all dosage. Syrups } \\
\text { not available }\end{array}$ \\
\hline \multirow[t]{2}{*}{$\begin{array}{l}\text { Health } \\
\text { Workforce }\end{array}$} & Staff & $\begin{array}{l}\text { General health care staff }+ \text { LPEP } \\
\text { Supervisor (1) and Research assistants (4) }\end{array}$ & $\begin{array}{l}\text { General health care staff, }+ \\
\text { LPEP Manager (1) and District } \\
\text { supervisors (3) }\end{array}$ & $\begin{array}{l}\text { General health care staff }+ \\
\text { LPEP manager ( } 1 \text { ) }\end{array}$ \\
\hline & Training & $\begin{array}{l}\text { LPEP operations and data } \\
\text { management training to } \\
\text { the staff before inception }\end{array}$ & $\begin{array}{l}\text { LPEP operations and data } \\
\text { management training to } \\
\text { the staff before inception }\end{array}$ & $\begin{array}{l}\text { LPEP operations and data } \\
\text { management training to the staff } \\
\text { before inception }\end{array}$ \\
\hline \multirow[t]{4}{*}{ Information } & Indicators & $\begin{array}{l}\text { Demographic, Epidemiology, } \\
\text { Clinical and coverage indicators }\end{array}$ & $\begin{array}{l}\text { Demographic, Epidemiology, } \\
\text { Clinical and coverage indicators }\end{array}$ & $\begin{array}{l}\text { Demographic, Epidemiology, Clinical } \\
\text { and coverage indicators }\end{array}$ \\
\hline & $\begin{array}{l}\text { Data } \\
\text { Management }\end{array}$ & $\begin{array}{l}\text { Electronic data entry at district } \\
\text { level by RAs in standard database } \\
\text { (similar in all countries) }\end{array}$ & $\begin{array}{l}\text { Electronic data entry at district } \\
\text { level by SAs in standard database } \\
\text { (similar in all countries) }\end{array}$ & $\begin{array}{l}\text { Electronic data entry at district level } \\
\text { by DLO in standard database } \\
\text { (similar in all countries) }\end{array}$ \\
\hline & Supervision & $\begin{array}{l}\text { Filed supervision by LPEP staff } \\
\text { (daily bases), National program } \\
\text { (periodic), International partners } \\
\text { (twice a year) }\end{array}$ & $\begin{array}{l}\text { Filed supervision by LPEP staff } \\
\text { (daily bases), National program } \\
\text { (periodic), International partners } \\
\text { (twice a year) }\end{array}$ & $\begin{array}{l}\text { Filed supervision by LPEP staff } \\
\text { (daily bases), National program } \\
\text { (periodic), International partners } \\
\text { (twice a year) }\end{array}$ \\
\hline & Reporting & $\begin{array}{l}\text { Monthly, quarterly and Annually. } \\
\text { Bottom-up at all levels }\end{array}$ & $\begin{array}{l}\text { Monthly, quarterly and Annually. } \\
\text { Bottom-up at all levels }\end{array}$ & $\begin{array}{l}\text { Monthly, quarterly and Annually. } \\
\text { Bottom-up at all levels }\end{array}$ \\
\hline Innovation & Initiatives & $\begin{array}{l}\text { Rifampicin available in syrup } \\
\text { for pediatric cases }\end{array}$ & No initiatives identified & $\begin{array}{l}\text { Hand fan with leprosy and } \\
\text { self-screening information. }\end{array}$ \\
\hline \multirow[t]{2}{*}{ Financing } & Funding & $\begin{array}{l}\text { Majorly Govt. funds. NGO } \\
\text { funding only for LPEP staff, } \\
\text { monitoring and trainings }\end{array}$ & $\begin{array}{l}\text { Majorly Govt. funds. NGO funding } \\
\text { only for LPEP staff, monitoring } \\
\text { and trainings }\end{array}$ & $\begin{array}{l}\text { Majorly Govt. funds. NGO } \\
\text { funding only for LPEP staff, } \\
\text { monitoring and trainings }\end{array}$ \\
\hline & $\begin{array}{l}\text { Funds } \\
\text { disbursement }\end{array}$ & $\begin{array}{l}\text { On time disbursement of NGO } \\
\text { funds. The government funds } \\
\text { disbursement depends on national } \\
\text { program's status }\end{array}$ & $\begin{array}{l}\text { On time disbursement of NGO funds. } \\
\text { The government funds disbursement } \\
\text { depends on national program's status }\end{array}$ & $\begin{array}{l}\text { On time disbursement of NGO funds. } \\
\text { The government funds disbursement } \\
\text { depends on national program's status }\end{array}$ \\
\hline \multirow[t]{2}{*}{ Governance } & Strategy & $\begin{array}{l}\text { Extended contact tracing, including } \\
\text { social contacts (school children) }\end{array}$ & Extended contact tracing & $\begin{array}{l}\text { Extended contact tracing } \\
\text { with self- screening }\end{array}$ \\
\hline & Integration & Integrated into general health system & Integrated into general health system & $\begin{array}{l}\text { Integrated into general } \\
\text { health system }\end{array}$ \\
\hline
\end{tabular}

ANM Auxiliary Nurse Midwife, ASHA Accredited Social Health Activist, DLO District Leprosy Officer, FCHV Female Community Health Volunteer, HH Household, IEC Information Education Communication, LFP Leprosy Focal, LO Leprosy Officer, NGO Non-governmental Organization, PMW Multipurpose Worker, RA Research Assistant, SA Statistical Assistant, SDR Single Dose of Rifampicin

\section{Conclusions}

We conclude that LPEP approaches can be integrated into different health systems without major structural and personal changes, but provisions are necessary for the additional monitoring needs. In the first year LPEP faced some challenges, but the program overcame these 
because of the committed attitude of the health care staff and officials. Intensive supervision and training developed the human resource capacity to implement similar programs in the future.

The London Declaration highlighted that strong and committed health systems are essential to achieve the 2020 targets for leprosy and other NTDs [4]. Therefore, all actions at the local or international level should contribute to health system strengthening [25]. Evidence suggests that integration strengthens the general health care systems and also enhances the efficiency and sustainability of the disease specific activities if applied properly $[31,38]$. Based on the above principles, LPEP was designed and successfully started its operations in coordination with the respective national programs. The next course of action is to apply the findings of this study, while assessing the impact of LPEP in future.

\section{Additional files}

Additional file 1: Staff Interview Questionnaire for Phase I and II. (DOCX $15 \mathrm{~kb}$ )

Additional file 2: The national strategies on leprosy control/elimination adopted by India, Nepal and Indonesia. (DOC $35 \mathrm{~kb}$ )

\section{Abbreviations \\ DNH: Dadra and Nagar Haveli; IEC: Information Education and Communication; LPEP: Leprosy Post-Exposure Prophylaxis; MDT: Multi-drug therapy; NCDR: New Case Detection Rate; NLCP: National Leprosy Control Program; NLEP: National Leprosy Elimination Program; NTD: Neglected Tropical Diseases; PEP: Post-Exposure Prophylaxis; SDR: Single Dose Rifampicin; UT: Union Territory; WHO: World Health Organization}

\section{Acknowledgements}

We would like to thank the Government Health Department and NLR officials in India, Nepal and Indonesia for providing all the necessary support in conducting the field work. We would also like to thank the health care staff in all the three countries for their participation and time. The scientific advice has been provided by the below members of LPEP Study Group: Christa Kasang (German Leprosy and Tuberculosis Relief Association, Tanzania), Ingrid Mason (FAIRMED, Switzerland), Paul Saunderson (American Leprosy Missions, USA), Peter, Steinmann (Swiss Tropical and Public Health Institute, Switzerland), Tanja Barth-Jaeggi (Swiss Tropical and Public Health Institute, Switzerland), David Blaney (Centers for Disease Control and Prevention, USA), Fareed Mirza (Novartis Foundation, Switzerland), Bart Vander Plaetse (FAIRMED, Switzerland), Ann Aerts (Novartis Foundation, Switzerland), Arielle Cavaliero (Novartis Foundation, Switzerland), Cairns Smith (Institute of Applied Health Sciences, School of Medicine and Dentistry, University of Aberdeen, UK), Wim van Brake (Netherlands Leprosy Relief, The Netherlands), Chrystel Dayer (CIOMAL, Switzerland), Hugh Cross (American Leprosy Mission), Tin Shwe (American Leprosy Mission, Myanmar), Anil Kumar (National Leprosy Elimination Program, Government of India), Basu Dev Pandey (National Leprosy Control Program, Government of Nepal), Rita Djupuri (National Leprosy Control Program, Government of Indonesia), Nandlal Bastola (Netherlands Leprosy Relief, Nepal), Teky Budiwan (Netherlands Leprosy Relief, Indonesia), Tin Maung Aye (National Leprosy Control Programme, Government of Myanmar), Beatrice Mutayoba (National TB and Leprosy Programme, Government of Tanzania), Deus Kamara (National TB and Leprosy Programme, Government of Tanzania), Blasdus Njako (Germany Leprosy and TB Relief Association, Tanzania), Nilanthi Fernando (Anti Leprosy Campaign, Government of Sri Lanka), Supun Wijesinghe (Anti Leprosy Campaign, Government of Sri Lanka), Nayani Suriyarachchi (FAIRMED, Sri Lanka), Lay Sambath (National Leprosy Elimination Program, Government of Cambodia), Rosa Castalia (Government of Brazil), Eliane Ignotti (Mato Grosso State University, Brazil).

\section{Funding}

This work was supported by Novartis Foundation. There was no role of the funding body in the design of the study and collection, analysis, and interpretation of data and in writing the manuscript. However, scientific advice was received from funders, as a part of LPEP study group.

\section{Availability of data and materials}

All data generated or analysed during this study are included in this published article [and its Additional files].

\section{Authors' contributions}

AT, LM and JHR conceptualized the study. AT, LM, KD, MA and SD collected data. AT, LM analysed the data and JHR supervised the analysis. All authors contributed equally in writing the manuscript. Scientific advice was provided by LPEP study group. All authors read and approved the final manuscript.

\section{Ethics approval and consent to participate}

This study was conducted under the LPEP program. The ethics approval for LPEP was obtained from the Institutional Human Ethics Committee, National Institute of Epidemiology, Indian Council of Medical Research (NIE/IHEC/ 201407-01) and Ethical Review Board, Nepal Health Research Council (NHRC 39/2015). There was no need for ethical clearance in Indonesia as post exposure prophylaxis was already a part of national leprosy control strategy. A verbal consent was sought from the respondents. No individual identifiable data were recorded.

\section{Consent for publication}

Not applicable.

\section{Competing interests}

The authors declare that they have no competing interests.

\section{Publisher's Note}

Springer Nature remains neutral with regard to jurisdictional claims in published maps and institutional affiliations.

\section{Author details}

${ }^{1}$ Department of Public Health, Erasmus MC, University Medical Center Rotterdam, Office Na 2219, Wytemaweg 80, 3015 CN Rotterdam, The Netherlands. ${ }^{2}$ Netherlands Leprosy Relief, Amsterdam, The Netherlands. ${ }^{3}$ Netherlands Leprosy Relief, Kathmandu, Nepal. ${ }^{4}$ Netherlands Leprosy Relief, New Delhi, India. ${ }^{5}$ Netherlands Leprosy Relief, Jakarta, Indonesia.

Received: 30 November 2016 Accepted: 10 September 2017 Published online: 29 September 2017

\section{References}

1. Rinaldi A. The global campaign to eliminate leprosy. PLoS Med. 2005;2(12):e341.

2. Lockwood DN. Commentary: leprosy and poverty. Int J Epidemiol. 2004;33(2):269-70.

3. Tsutsumi A, Izutsu T, Islam AM, Maksuda AN, Kato H, Wakai S. The quality of life, mental health, and perceived stigma of leprosy patients in Bangladesh. Soc Sci Med. 2007;64(12):2443-53.

4. Country Leadership and Collaboration on Neglected Tropical Diseases: Third progress report of the London Declaration. http://unitingtocombatntds.org/ sites/default/files/resource_file/london_declaration_on_ntds.pdf. Accessed 9 Nov 2016.

5. Global leprosy update, 2014: need for early case detection. Wkly Epidemiol Rec. 2015;90(36):461-74

6. Lockwood DN, Shetty V, Penna GO. Hazards of setting targets to eliminate disease: lessons from the leprosy elimination campaign. BMJ. 2014;348:91136.

7. Roemer MI. National Health Systems of the World: The countries. vol. 1: Oxford University Press; 1991.

8. World Health Organization. Enhanced Global Strategy for Further Reducing the Disease Burden Due to Leprosy, Plan period: 2011-2015. 2009. http://www.searo.who.int/entity/global_leprosy_programme/documents/ enhanced_global_strategy_2011_2015.pdf. Accessed 26 Nov 2016.

9. World Health Organization. Global Leprosy Strategy 2016-2020: Accelerating towards a leprosy-free world. 2016. http://www.paho.org/hq/index. php?option=com topics\&view=article\&id=30\&ltemid=40755\&lang=en. Accessed 26 Nov 2016. 
10. Richardus JH, Habbema JD. The impact of leprosy control on the transmission of M. Leprae: is elimination being attained? Lepr Rev. 2007;78(4):330-7.

11. Smith WC, Aerts A. Role of contact tracing and prevention strategies in the interruption of leprosy transmission. Lepr Rev. 2014:85(1):2-17.

12. Saunderson PR. Leprosy elimination: not as straightforward as it seemed. Public Health Rep. 2008:123(2):213-6.

13. Bratschi MW, Steinmann P, Wickenden A, Gillis TP. Current knowledge on mycobacterium leprae transmission: a systematic literature review. Lepr Rev. 2015;86(2):142-55.

14. Fine PE. Leprosy: what is being "eliminated"? Bull World Health Organ. 2007;85(1):2.

15. Richardus JH, Oskam L. Protecting people against leprosy: chemoprophylaxis and immunoprophylaxis. Clin Dermatol. 2015;33(1):19-25.

16. Smith WC. Sustaining anti-leprosy activities requires radical changes. Lepr Rev. 2010;81(4):281-3.

17. Smith CM, Smith WCS. Chemoprophylaxis is effective in the prevention of leprosy in endemic countries: a systematic review and meta-analysis. J Inf Secur. 2000;41(2):137-42.

18. Moet FJ, Pahan D, Oskam L, Richardus JH. Effectiveness of single dose rifampicin in preventing leprosy in close contacts of patients with newly diagnosed leprosy: cluster randomised controlled trial. BMJ. 2008;336(7647):761-4.

19. van Brakel W, Cross H, Declercq E, Deepak S, Lockwood D, Saunderson P, et al. Review of leprosy research evidence (2002-2009) and implications for current policy and practice. Lepr Rev. 2010;81(3):228-75.

20. Yin RK. A brief refresher on the case study method. vol. 34. 3rd ed. Washington DC: SAGE Publications; 2012.

21. Barth-Jaeggi T, Steinmann P, Mieras L, Wv B, Richardus JH, Tiwari A, et al. Leprosy post-exposure prophylaxis (LPEP) programme: study protocol for evaluating the feasibility and impact on case detection rates of contact tracing and single dose rifampicin. BMJ Open. 2016;6:e013633.

22. World Health Organization. Everybody's Business: Strengthening Health Systems to Improve Health Outcomes. 2007. http://www.who.int/ healthsystems/strategy/everybodys_business.pdf?ua=1. Accessed 9 Mar 2016

23. Mounier-Jack S, Griffiths UK, Closser S, Burchett H, Marchal B. Measuring the health systems impact of disease control programmes: a critical reflection on the WHO building blocks framework. BMC Public Health. 2014;14:278.

24. Scollard DM. Leprosy research declines, but most of the basic questions remain unanswered. Int J Lepr Other Mycobact Dis. 2005;73(1):25-7.

25. Frenk J. The global health system: strengthening national health systems as the next step for global progress. PLoS Med. 2010;7(1):e1000089.

26. Hafner T, Shiffman J. The emergence of global attention to health systems strengthening. Health Policy Plan. 2013;28(1):41-50.

27. Sandle T. Global strategies for elimination of leprosy: a review of current progress. J Anc Dis Prev Rem. 2013;1(4):e112.

28. Collins CD, Green AT, Newell JN. The relationship between disease control strategies and health system development: the case of TB. Health Policy. 2002;62(2):141-60

29. Levesque JF, Harris MF, Russell G. Patient-centred access to health care: conceptualising access at the interface of health systems and populations. Int J Equity Health. 2013;12(18):18.

30. Kruk ME, Freedman LP. Assessing health system performance in developing countries: a review of the literature. Health Policy. 2008;85(3):263-76.

31. Feenstra $P$, Visschedijk J. Leprosy control through general health services-revisiting the concept of integration. Lepr Rev. 2002;73(2):111-22.

32. Visschedijk J, Engelhard A, Lever P, Grossi MA, Feenstra P. Leprosy control strategies and the integration of health services: an international perspective. Cad Saude Publica. 2003;19(6):1567-81.

33. Ministry of Health and Family Welfare, Government of India. Outcome Budget 2014-15 for Department of Health and Family Welfare. 2015. http://www.mohfw.nic.in/WriteReadData/l892s/6FinancialOutlays OutcomeBudget201415.pdf. Accessed 9 Nov 2016.

34. Ministry of Health and Family Welfare, Government of India. Outcome Budget 2015-16 for Department of Health and Family Welfare. 2016. http://www.mohfw.nic.in/WriteReadData/l892s/6541236578963214.pdf. Accessed 9 Nov 2016

35. Ekman B. Community-based health insurance in low-income countries: a systematic review of the evidence. Health Policy Plan. 2004;19(5):249-70.

36. Lagomarsino G, Garabrant A, Adyas A, Muga R, Otoo N. Moving towards universal health coverage: health insurance reforms in nine developing countries in Africa and Asia. Lancet. 2012;80(9845):933-43.
37. Chandler DJ, Hansen KS, Mahato B, Darlong J, John A, Lockwood DN. Household costs of leprosy reactions (ENL) in rural India. PLoS Negl Trop Dis. 2015;9(1):e0003431.

38. Unger JP, Paepe PD, Green A. A code of best practice for disease control programmes to avoid damaging health care services in developing countries. Int J Health Plann Manag. 2003;18(Suppl 1):S27-39.

\section{Submit your next manuscript to BioMed Central and we will help you at every step:}

- We accept pre-submission inquiries

- Our selector tool helps you to find the most relevant journal

- We provide round the clock customer support

- Convenient online submission

- Thorough peer review

- Inclusion in PubMed and all major indexing services

- Maximum visibility for your research

Submit your manuscript at www.biomedcentral.com/submit 